\title{
Land Exclusion of the Former East Timorese Refugees in Belu Regency, West Timor
}

\author{
Farid Abud Alkatiri \\ Department of Sociology \\ Faculty of Social and Political Sciences \\ University of Indonesia \\ Indonesia
}

\begin{abstract}
The purpose of this dissertation is to analyze social problems, which relate to the land access issue faced by Timorese refugees in Belu Regency since their arrival in 1999. From the government's point of view, one of the solutions is to implement the resettlement program. However, many believe the program means land exclusion. This study uses the qualitative method, the data has been collected through in-depth interviews and direct observation, and includes some secondary sources to complement the main findings. This research has included social institution perspectives, especially family institutions, to analyze the implications for family and ethnic ties of the land access problem within the former refugees' community. The result of this research shows that the family and ethnic ties affect the processes of land access, which is sometimes used by certain figures within the former refugees and local community or institution to achieve social, political, and economic interests, excluding them from land access. To overcome the problem, the former refugees have used social and political networks as well as cultural approaches to derive any support towards coping strategies of land access.
\end{abstract}

Keywords: Land Exclusion, Institution, Refugee, Family and Ethnic Ties

\section{Introduction}

The 1999 referendum in East Timor has left several unresolved issues for the local government of Belu. The political mechanism was held to choose whether for East Timor to choose becoming an independent nation or to continue to be part of Indonesian territory. The referendum led to East Timor becoming an independent nation. However, several social and political groups were not satisfied with the result, and began to devastate towns and villages in the country. This, in turn, created internally displaced persons, others who had to migrate to Indonesian territory like the Belu Regency.

As a border territory, Belu Regency hosts hundreds of thousands of East Timorese refugees. According to Knezenic (2005), 250.000 to 280.000 people moved to the regency in 1999 because of fear of the conflict, and then lived in scattered refugee camps that existed in the territory of Belu Regency. Achmad (2000) mentions that the number of refugees fell to 135.689 as a result of the repatriation program introduced in the year 2000, along with resettlement and transmigration programs. Moreover, the number of repatriations has decreased even further. A report of the East Timorese refugees' forum in Belu, called KOKPIT has shown that the number of refugees is estimated around 80.000 to 100.000 (KOKPIT report, 2011). They have decided to live in the regency as Indonesian citizens.

The living conditions in the camps were poorly organized by the local government because they were unprepared for the vast numbers of refugees coming to the regency (Achmad, 2000), although social assistance has been given and distributed continually to the refugees. In 2002, all national and international donors stopped distributing the assistance because of the unconducive situations and the lack of exact data concerning the lives of the refugees. The following year, the local government announced that the government has not provided land for the resettlement program because of lack of financial support and accessible land. The only assistance given to the refugees was building materials. Therefore, the land for the resettlement program had to be provided by the refugees themselves. The decision of local government created a burden for the refugees, because they had to cope with social and economic problems as well. Besides that, the status of refugees was withdrawn in 2005 by the central government. 
The decision was made because the government considered that the refugees question had been solved, in spite of the fact that the issue of land was still unresolved. Land access is a crucial issue for most of the refugees, not only as living space, but also for gaining a livelihood in the agricultural sector. Therefore, searching for land became apriority. The same refugees faced several other obstacles. They were excluded from many areas, as mentioned in the findings of Hall et al (2013), such as regulation, force, market, and legitimation. These four areas are in addition to the land exclusion problem faced by the former East Timorese refugees in Belu Regency.

In this research, the social institutions, such as family and local political institutions have played important roles in land exclusion. It has connections with refugee family's values and the dynamic of the internal refugee community based on ethnic ties. Therefore, this article investigates how the processes of land exclusion based on family values and ethnic ties takes place and how the roles the village government and the local figures have played in excluding the refugees from housing and land access.

\section{Literature Review}

Refugees or other "problematic" groups commonly face the issue of land exclusion. It has strongly connected with multidimensional aspects of life which may be considered as constraining factors. Several studies have been undertaken to study the issue. Agblorti (2011) considers that the land access problem has been caused by the lack of a process of integration between refugees and the local host community. Meanwhile, other researchers have considered conflicts which emerged between the refugees and the local community. Studies in Indonesia and Africa have showed that dissatisfaction and feelings of disappointment with the refugees' presence and occupation of the locals' land lead to conflicts. Consequently, the refugees' community may lose land access' opportunities, especially for the peasants (Duncan, 2000; Martin, 2005; Okumune and Bonome, 2010; and Bohnet, 2012).

Several studies of the land access problems of the former East Timorese refugees have also been conducted in two regencies, in Belu and Kupang, East Nusa Tenggara Province. Messakh (2003) believes that the existing issue of land access in Belu has occurred because of the lack of government's own land that could be offered to the former refugees. Besides that, Messakh sees that the sporadic development of camps and resettlements is also a contributing factor. The local government has no records of the government land. One of the existing problems is that the claim of the traditional institutions over the land across the regency clashes with assumptions of the local government relating to the said land. Other findings came from Rame (2005) and Sianipar (2016) who have indicated that the problem of land exclusion has been caused by the unclear resettlement policy of the local government of Belu in relation with the status and ownership of resettlement's land. The findings of Pirade (2003) in Kupang has shown that the issue is strongly related to land struggle between the former refugees with the people and the landlords, therefore the activities of the former refugees as peasants has been limited.

A recent study about land access has come from Hall et al (2013) who conducted studies in the countries across Southeast Asia. In their findings, Hall et al concluded that land exclusion has occurred because of four powers of exclusion. The four powers of exclusion consist of regulation, force, market, and legitimation. Hall et al see that the four powers have played major roles in any attempts to access land. Each power of exclusion becomes a supporting factor for the other in excluding particular individuals or groups in various sectors, associated with agricultural, environmental, or the use of land based on regulations.

One of the basic argumentations in the land access issue is the perspective of powers of exclusion coined by Hall et al (2013). To some extent, the perspective originates from the theory of access, coined by Jesse Ribot and Nancy Peluso. According to Ribot and Peluso (2003), access is associated with "the ability to benefit from things". This point of view has been further developed by Hall et al in the context of land exclusion in the Southeast Asian countries. Hall et al see that land exclusion is "ways in which people are prevented from benefiting from things". In their opinion, exclusion is not only limited to property ownership, but also involves "socially acknowledged and supported claims or rights".

Furthermore, Hall et al (2013) provide a framework for looking at land exclusion. They categorize four powers as constraining aspects in accessing land. The four constraints are regulation, force, market, and legitimation. According to Hall et al, regulation is a fundamental aspect regarding the categorization for the use of land and clams of ownership. It is associated with both formal and informal laws. 
According to Hall et al, powers of regulation and force may become as one important part because force is the heart of regulation used to protect the interest of actors. Moreover, regulation is also supported by the power of market through marketization of land in order to formalize the ownership of land (Hirsch, 2016). It can be found in several government programs such as the land titling program and land reform. However, Sayogyo (2009) sees that the transfer of control and ownership of land can be done through manipulative regulation or force.

The use of force my cause land exclusion for certain individuals or groups. It occurs because of an imbalance in power relations. Usually, powerful actors to achieve or maintain the interests use it. It may be used by state or other entities and involve security institutions to defend the interests of powerful actors. Hirsch (2016) sees that the use of power of force is strongly connected with the issue of control of land.

Hall et al argue that the power of the market plays an important role in the land exclusion problems through land price mechanisms which are considered as the determinant aspect of land exclusion. Land price is used to get land or to maintain claims, therefore it becomes the main focus in order to understand the dynamics of land exclusion in Southeast Asia. According to Harms, the common phrase used in regulation in the context of land exclusion is "it is not allowed", meanwhile the famous phrase in power of market is "cannot afford". Furthermore, Hall et al argue that power of market become a parameter of other powers of exclusion.

Legitimation has different characteristics as it is connected with justification reasons as the basis of judgement on the use of land. The presence of power of legitimation is to support any argument on behalf of development, civilization, modernity, and environment. In practice, investment in the agricultural sector of multinational companies for the purposes of development can victimize small scale farmers through land grabbing. Besides that, legitimation also is linked to moral argumentation within community relations, including traditional institutions, decision making, and representation of the powerful stakeholders. Hall et al stress that the power of legitimation is influenced by the power of market, which reflects a continued process of intimate exclusion between strong actors with weak individuals or groups.

However, these studies mentioned above have not discussed the dynamics of the former refugees internal community as a constraining factor that within the community. The collected data in this research has shown that the former refugees' family institution has also significant impact on the land access issue. This has occurred through family and ethnic ties and values, which are strongly embedded in the individuals' and groups' perspectives, especially associated with their status. Besides that, the village government and the certain figures at community level also have played crucial roles in the processes, through their powers.

\section{Theoretical Framework}

Land exclusion has become a main concern for scholars, especially in developing countries (Rodgers, 1995). According to Rodgers, study of land exclusion in developing countries is still rarely found. According to some researchers' perspectives, land access and social exclusion have strong relations, especially when discussing economic resources issue as one of the central themes of social study (Rodger, 1995 and Hall et al, 2013), therefore according to Silver (as cited in Sen, 2000) it is considered as material exclusion. Therefore, it may rise up the issue of material exclusion (Sen, 2000), leading to the conflict and land struggle potencies (Unruh and Williams, 2013 and Rodgers, 1995).Meanwhile, Banki (cited in Celik, 2012) views that one of the few aspects for refugees to integrate into to a society is having access to land.

In order to understand profoundly the causes and process of land exclusion of the former East Timorese refugees in Belu Regency, it is insufficient to use only the powers of exclusion perspectives mentioned above. Meanwhile, the problem of land exclusion at micro level should be seen through family institution and ethnic ties, and power relations between the refugees with the local community through village government and local figures. Therefore, this research has used some perspectives of social institutions to investigate and analyze the issue with a new insight to understand land exclusion of the former refugees in Belu Regency.

From theoretical perspectives, studies concerning land access and family institutions are still rarely found, although political institutions and land access problems have been mentioned in several previous studies. Silver (2007) argues that other parties, such as neighbors and friends, may influence decision making in family institution particularly. It is because life is structurally institutionalized and to some extent implicates the achievement of the family's welfare. As a consequence, it limits mobility and traps individuals and groups into poverty. 
The connection between land exclusion and family institution is also discussed by Steenbergen (cited in Chau and $\mathrm{Yu}, 2001$ ) and Hayes (2008) who see that exclusion occurs in a family because of the existence of institutions as obstacles in the process of participation in a society, lack of social relations, and fewer opportunities. For Pierson (2002) exclusion occurs as consequence of manifestation of the lack of social protection and social cohesion within the family institution, kinship, neighborhood, and community. Pierson (cited in Seda et al, 2017) and Roca (cited in the Peduli Program report, 2016) argue that neighborhood and local environment also have significant effects in shaping exclusion within ethnic or any other communities. Furthermore, Roca stresses that migrant community is easily excluded because of internal problems of the community. Meanwhile, exclusion is not only related to the excluded groups, it also connects with people who are self-excluded from society. To overcome the issue Silver (2007) and Zid and Alkhudri (2016) propose that a social network is needed to maintain opportunities, if the networks and ties are used properly.

In political institution, social exclusion is a condition where someone or group have not gained powers and strong social relations. Therefore, a political institution is needed to manage politically participation and decision making in order to provide enough space for the excluded parties (Silver, 1995). In order to manage and maintain the balance of power, the state is seen as the major architect of social policy that can integrate all parties on the basis of shared citizenship (Vidojevic, 2017). Atkinson (cited in Hayes et al, 2008) argues that the key to maintain participation and welfare is decision making which is considered as the determinant aspect. Atkinson believes that exclusion is caused through unilaterally decision making of an individual, group, and institution at the level of government and society, causing the unfulfillment of citizens' rights.

Besides having decision making as an initial process of exclusion, Veneklasen et al (2006) sees that exclusion is also maintained through control post decision making process to erase representation values of the excluded parties. Kadun and Gadkar (2014) illustrate the condition above as it occurs in the Dalit community in India, which is excluded by the government institution from various aspects of life, leading to discrimination. In the DFID Social Exclusion review, Beall and Piron (2005: 10) declares that exclusion is considered as a process occurring within social institution which creates powerful groups that may practice discrimination towards certain other groups.

\section{Research Method}

This study has used a qualitative method, focusing on indepth interviews, observation, and secondary data. The interview processes and observations have been conducted from October 2016 until February 2017 in five studied areas, such as resettlement of Taeksoruk, Resettlement of Tohe, Resettlement of Weliurai, Resettlement of Halimuti, Resettlement of Raibasin, and refugee camps of Haliwen and Cabang P.U. Besides that, interviews were also conducted with several officials of the local government, members of the local assembly, the local village authorities and figures, and the former refugees' representatives. The secondary data has been used as complementary data, to compare and distinguish the previous studies' findings with this research.

\section{Results and Discussions}

The various studies have shown that land exclusion faced by a group of refugees is commonly caused by either a government policy or bad relationships with the host community. However, the findings of this research have showed that one of the major issue of land exclusion is caused by the internal dynamics of the refugees' community, especially the influence of family and ethnic ties, cultural obligations, and individual or group affiliations and interests as well as perceptions of being refugees.

\section{The Powers of Exclusion of the Land Access of The Former Refugees}

Almost all researchers agree that land is a crucial asset for most of the people. From cultural and social perspectives, Reydon and Brass (cited in Bijikumar, 2013) see that land is a symbolic representation of a tradition or value of a society. Meanwhile, Borras and Franco (2010) point out that land is fundamental aspect of social life and politics of the elites or certain groups.

It was unexpected that the number of East Timorese refugees coming to the Belu regency would reach 250.000 up to 280.000 people. As a result, both central and local governments faced difficulties in handling all of the social issues involved. The camps of refugees have been built sporadically and the movement around and the situation of the regency was uncontrolled. In order to prevent the spreading of social problems, the government decided to build resettlements in various places. 
The placement of refugees in the various resettlement did not take into account any legal matters, especially the issue of the land's status. The study of Messakh (2003) has shown that the local government did not have enough land to be provided for the resettlement program, as a result, the camps and resettlement were built sporadically.

In order to handle the issue of the lack of land, the local government has preferred to make cultural and social approaches to the local tribes and landlords to borrow their land temporarily. The policy of the local government is to prioritize the resettlement program. The program has to be carried out rapidly due to the humanitarian reasons, and preventing social problems in the camps. In doing so, the administrative and legal matters of the land status for the resettlement development were put aside.

From the year 2000 until 2003, most of the land of resettlement was given temporarily by landlords as well as the traditional institutions, called lembaga adat. These institutions are among the most powerful and legitimate social institutions at the local level. The main functions of the lembaga adat is to manage the traditional land and forest for its tribal members, including maintaining social and cultural values and norms. According to Hall et al (2013), the legitimation is strongly connected with judgements on the use of land, and sometimes using the moral argumentation to manage the land. In certain cases, Hall et al argue that legitimation may be combined with the powers of force and regulation to maintain the market interests.

In the perspective of lembaga adat in Belu regency, it is not allowed for outsiders to have access to the traditional land and forest, except if a temporary agreement is reached. For those who break the social and cultural norms, social and cultural punishment will follow. On the other hand, the former refugees have considered that the resettlement's land is believed to be their own land because it is seen as a part of the government resettlement program. The former refugees' perspective has contradicted the agreement between the local government with the lembaga adat, leading to the several land struggles and social conflicts in various resettlements, as occurred in the resettlement of Sirani in Umaklaran Village, resettlement of Taeksoruk of Fatuba'a village, and resettlement of Aitaman in Manleten village. Consequently, the use of land for the former refugees has been limited, and some of them have been excluded or expelled from the resettlement. This is the initial stage of the land exclusion problem.

However, it is insufficient to analyze the issue of land exclusion in the regency and to conclude that the problems are caused by government policy and community relationships. However, the land exclusion become a worse case because of contributions from the former refugees themselves. To understand the issue, it is important to analyze profoundly the dynamics of the former refugees' community in order to have better understanding of the whole land exclusion problem. Therefore, the issues of the family and ethnic relations and certain figures' political interests become interesting themes to be analyzed.

\section{Family Ties and Land Exclusion.}

Based on findings, the internal dynamics of the former refugees' family play important roles in shaping the way of thinking of land access. Since their arrival in 1999, most of the former refugees are already settled and live according to family and ethnic divisions, as is normally seen in the Timorese family. The family strong ties in the former refugees also have significant impact on the land exclusion this can be seen from various aspects.

\section{Family Ties and the Social Values of "Living Together"}

The issue of land exclusion and family ties are closely linked in the former refugees' families. In the Haliwen Camp, there are more or less 400 families, coming from different places and living together as a community based on kinship and ethnic background. The family ties are still strong within each community. They preferred to stay together in the camp instead of moving out to other places, although the land is freely offered by other entities. In fact; they need a piece of land for their agricultural activities and better living standard. The government has offered them the transmigration program, moving and living outside in the other territories in Indonesia. The transmigration program provides 2 hectares of land and house as a package for them. However they have rejected this program because of the anxiety that they may be divided into groups, living separately in different places. For them, living in a new place is challenging as it requires them to work and rebuild their life from the beginning. Therefore, they need to support each other in facing obstacles. The family tie is sometimes considered an obstacle to change for a better life. The former refugees expect that the local government provide them with a piece of land, so they can live together in one place. Until the present time, the government has no option to mobilize them in huge numbers. The only option for the local government is to evict them from the camp because the land belongs to the veterinary office property. The findings show that several families still need assistance due to the lack of purchasing power and difficulties faced if living in a nuclear family. 
Similarly, this situation is also found in another refugee's camp, called the Cabang P.U camp. The camp is occupied by several families. The social and economic conditions are poor, the living standard has not improved. The land is borrowed temporarily from a local landlord since the year 2000. All of the former refugees come from the same place, called Dili, however they are not relatives. It is a quite unique because the ties are bound up through group affiliation, then slowly shaping as a family based on trust and social solidarity. The former refugees in the Cabang P.U camp also prefer living together, although few of them may consider living separately as an option offered by the local government.

The family ties also feature in the resettlement of Weliurai, located in the village of Kabuna. The resettlement has become the most favorite place because it has already 10 resettlement locations. The village is nearby the city and public facilitation is quite well-provided for in the last five years. The land has been bought by the former refugees who moved to the location as their own initiative through group-support, and the houses were built by the central and local government as well as donors institutions. Each resettlement has different size of land due to financial constraints. The only difficulties are land for agricultural activities and water. Similarly, they live together based on family and ethnic ties and the conditions are below a basic living standard. Although the government offers them other options such as transmigration with enough land and houses, they prefer to live together, waiting for government or local people's support. Some of the former refugees have instigated a cooperative through crop sharing, with the landlords or local people. They borrow the locals' land and use it for agricultural activities, and the land has to be delivered back if it is needed by the landlords. There is no guarantee for them that they can use the land for a long time. As a result, some leave the agricultural sector and work in other informal sectors.

\section{Cultural Obligation Through Family Ties}

Besides having the social ties, cultural obligation and responsibility are entwined in aspects of the land issue. For many of them, cultural activities are part of life. The former refugees often practise several rituals and customs during the year straining their budget and reducing their purchasing power for their basic needs, especially land. It is well-known in the former refuges' communities and dominated by the Kemak ethnic in the regency. The Kemak ethnic is the most active of cultural practitioners and have the highest values and cultural expectations. Nevertheless, all efforts and commitments made to fulfill these cultural obligations; even they have to obtain a loan in order to buy animals, clothes, donating some money, and fulfilling other obligations.

Although the cultural demands are considered high and burden individuals, it all works through family ties and values as well as traditional institutions in order to be easily maintained and preserved by the members of family. The obligation and values are transferred from the elder people and parents to children, and strongly supported by traditional institutions or the lembaga adat, through social and cultural norms and sanctions. Therefore, it is quite difficult for them to step away from these obligations.

In the village of Silawan, the chief of the lembaga adat, called $\mathrm{Na}{ }^{\prime} i$, has proposed social norms to reduce the high cost of cultural obligation. It is also seen as a creative solution to prevent social conflict that may occur while the cultural obligation is taking place within or between the former refugees with the local families. The local families consider that the cultural habits and customs of the former refugees' come at a high price. Another way of social assistance is called Tuku Badu. It is the local wisdom of Silawan village, where people are gathered to assist a family in fulfilling a cultural demand, especially on the occasion of a wedding ceremony. These two forms of social assistance are examples which demonstrate that the cost of cultural obligation of the former refugees is high and it becomes one aspect in preventing them from having the land.

\section{The Roles of Prominent Figures and Coordinators: ethnic divisions, competition and distrust}

Living under ethnic division can be seen throughout the camps and resettlements. The former refugees have been divided into several ethnic groups, for instance Bunaq, Mambai, Tokodede, Maccasae, Dawan, and Kemak as the main ethnic group in Belu regency. The division is strong a factor obstructing land access. Normally, each ethnic group is divided into several small groups or blocks based on the level of political structure of the government. It is led by someone who is called as refugee coordinator. At the initial stage of their arrival, the duty of the coordinator is as a data collector and social assistance distributor to the refugees. At that time, the coordinators are separated into different levels, based on the numbers of the refugees. The lowest level of the coordinator can be found at the community level or called Rukun Tetangga, controlling of 30 to 50 families. Then, it is followed by the coordinator of camp or resettlement at a village level who may control up to 100 families. 
Furthermore, another higher level is called the coordinator of a sub-district, controlling hundreds of refugee families. It is followed by the coordinator of a district who is considered a prominent figure of the refugees, leading all coordinators in a district. The top position of the former refugees is headed by a chief of an organization, called UNTAS (Uni Timor As'wain), it is a political organization.

Besides having a political organization, the refugees have also established several social associations. The aims of the establishment are to harness the interests and provide social and economic solutions to the members. There are two organizations among others, called HIKBAT and KOKPIT. The organization of HIKBAT (Himpunan Keluarga Besar Atsabe), an association of the ethnic group of Kemak, based on the Haliwen refugee camp. This association is exclusively established to solve problems faced by the ethnic members of Kemak, having social and political networks with prominent figures of several officials of the local government. Meanwhile, KOKPIT (Komite Korban Politik Timor Timur) is an association of all political victims who have decided to stay as Indonesia citizens. The members of the KOKPIT is wider, consisting of all groups of refugees, including all Indonesian citizens who ever lived more than 5 years in East Timor.

The main problem of these political and social organizations is resource competition among coordinators or chiefs. After the status of refugees and social assistance have ended, the initial function of the former coordinators no longer exists. However, most of them have transferred themselves to be chiefs of the refugees at community level, head of ethnic organizations, or involved in political parties. However, the current position as chiefs is used to serve their individual and group establishing social networks to compete for social, political, and economic resources, especially land access. Besides that, money politics is obviously is seen as an instant ways to obtain voters. This condition is used by the local politicians and authorities in order to obtain votes and supports in the local political elections. The mobilization of the former refugees voters to support certain candidates occurs, dividing the former refugees into groups. For those politicians who wins the election and become top officials in the local government, will prioritize the refugees' supporters, formulating policies that fulfill the political contract, such as land and housing access. However, those who are considered as the losers may not be prioritized by the local government. It is explained by a coordinator that if their candidate is the winner in the election, then any proposal of social assistance can be directly submitted or contact made to the top official. As a consequence of this conflict of interests, the former refugees lose their political rights as Indonesian citizens and become a "political commodity" for coordinators, politicians, and officials in Belu.

An additional finding of this research, is the manipulative actions of the coordinators that has seen the distribution of social assistance such as housing development program, rice distribution, and cash transferred through altered documents. It is widely known that most of the coordinators still use the former refugee names as recorded in their old collected data to search for social assistance. As a consequence, the name of the former refugees is intentionally written twice - recipients without being verified by the local government or donor institutions. In fact, the recipients received a benefit only once or have moved out to different places.

The maneuvers of the former coordinators have created distrust within the former refugee's community. Most of the former refugees consider that coordinators are not honest searching for private interests on behalf of the former refugee's community. However, there are only few coordinators who are seriously solving the difficulties of the former refugees, especially the land and housing access issues either by social networks or distributing their own piece of land to refugees.

\section{The Impacts of the Former Refugees' Views On Their Status: between "refugee" and "hero"}

One particular group of the former refugees are those who were involved in the militias pro Indonesia, consisting of 13 groups. It is believed that there are thousands of them living in Belu. Similarly, land access also becomes an important issue for them, however, their basic views are making conditions even worse in comparison with the other refugees. The former militias groups view themselves not only as refugee, but also as a patriot who has ever defended the Indonesia state politically, showing their loyalty and commitment as Indonesian citizens. The reconciliation between the government of Indonesia and East Timor has not motivated them to return to East Timor, on the contrary; they are willing to leave their relatives, properties, land in East Timor for the sake of Indonesia. This view has impacted indirectly on their ways of thinking in relation to their status $t$ they see themselves as heros. Therefore, the Indonesian government has to fulfill their basic necessities, including providing land and houses for them. This opinion makes them become passive refugees, waiting for assistances from the government. Thus, the majority of them do not put much effort to search for their own land, and as a result they still live in the camp of refugees or the land of the local people. 
During this time, they consider that the government of Indonesia does not fulfill their rights as heros and citizens, feeling that their struggle is less appreciated post the referendum of September 1999. At the present time, they still expect that the Indonesian government complies with its commitment to reciprocate their sacrifice.

\section{Land Access Strategies: some stories of the land struggle}

In order to survive, the former refugee has to find certain strategies or mechanisms to obtain the land sometimes even out of a situation of exclusion. The first strategy is moving themselves out of the camp of refugees through their own initiative or self-supporting mechanism. It is only a few refugees who have succeeded mainly because of financial difficulties. Generally, it is only prominent refugees' figures or those whose wealth was enough for them to decide moving out with any other support. They have moved out of the camp or the resettlement, purchasing a wide area of land, dividing the land into small and medium size and selling to who are interested moving out from the camp or resettlement. Normally it is sold at special price to relatives or friends. This initiative has been based on the social solidarity between them to begin a new life in different location. There is no other choice for some peasants who have purchased a small piece of land, except having a crop sharing cooperation with the landlords. It may not be a really successful example, but at least they are not trapped in the maneuver of certain coordinators or become apolitical "commodity" for other parties. This mechanism is found in the resettlement of Raibasin, Manleten village, which is located around $13 \mathrm{Km}$ from the city of Atambua.

Another pattern is moving out from the refugee camp through group-supporting mechanism based on family or ethnic ties. This mechanism has been used by few groups of the former refugees. This mechanism assists those who have a financial limitation. The budget for land purchasing is collectively and equally collected among members of family. After that, they look for a vast area based on three criteria: productive land, water access, and strategic location. It is difficult to find the 3 criteria in a piece of land in the regency due to the natural resources limitations. If potential land is found, then the negotiation with the local people or landlords is commenced. Normally, the negotiation takes place according to local customs, called sirih-pinang. It is a market-cultural combined approach, where the price of land is negotiated but it involves a cultural approach. The function of the local wise person is to present the kinship or ethnic nuance. This way may reduce the land price. If the price is accepted, then the process of payment is finalised, the former refugees may submit a proposal to the local government for the resettlement housing program development. Most of the resettlement in Kabuna and Tohe villages is built through this pattern.

The most successful story so far comes from resettlement of Tohe, which is closely located in the border territory between Indonesia and East Timor. There are around 1.500 families of the former refugees living in that resettlement. The issue of land has hardly featured at all. Many of the former refugees have bought their land from the locals because the land is considered cheaper, although a few of them still have leased the land with the crop sharing agreement. The land is planted with commodities, such as vegetables, red pepper, fruits, that may produce a quick return, whereas, the local peasants plant rice where the harvest period is once a year only. By having land and agricultural activities, the former refugees of Tohe can fulfill their basic needs without waiting for social assistance from the government, moreover they send their children to higher education in Kupang or Jawa. Besides that, there are some advantages of living in the border area. It is not difficult to market their agricultural or home-made products. Besides having daily markets, they are visited by their relatives or consumers coming from East Timor at the market of Turiscain on Tuesdays and Fridays.

Besides having successful strategies of land access, the other former refugees have faced risks in deciding land access strategies. The former refugees living in the resettlement of Taeksoruk used a unique strategy. In 2016, the former refugees made an approach to the tribe to accept them as new members of the tribe. The purpose of the approach is to maintain social relations as well as creating the opportunity to obtain land access, either to derive more productive land for agricultural activities or to have a permanent land titling. The event has held with a traditional approach and led by the lembaga adat of Liudasik tribe. One important point is that the former refugees will be expelled away from the land. Moreover, the former refugees have been mobilized to vote for a candidate who is a member of the tribe in the village election. The candidate has promised to solve the land issue. The candidate has won the election with the support of the former refugees, leading with 7 votes in the voting place of the resettlement. However, becoming the new member of the tribe and supporting a candidate in the village election have not changed their status as a "refugee". The land access issue has not been solved yet. The tribe seems to reject the handover the land to the former refugees, rejecting transfer of ownership of the resettlement land, feeling uncertainty towards them. 
Since the status of refugees has been withdrawn, the former refugees try to find other solutions to obtain social assistance, especially land and housing accesses. Political approach tends to be a favorite approach for them, bartering between voting supporters of the former refugees with political position of prominent politicians at government or community level. This approach also makes chiefs or prominent figures of the former refugees and gives direct political and social access to the top official figures at government level.

Those strategic approaches show that the local and central government were in a rush in withdrawing the status of refugee in 2005 . The issue should have been solved properly before making any decisions and considerations regarding the status of the former refugees.

\section{Conclusion}

Land exclusion is a crucial problem for the most of the former refugees of East Timor in Belu Regency. For many years, they have lived with uncertainties, such as the conditions of the land status and ownership. It began with the local government resettlement policy, moving them out of camps and leaving them in the landlords or the local tribes' land. In Belu, land is mostly occupied by local tribes and managed by the powerful institution, called the lembaga adat. There are several resettlements which have been built on the tribes' land. Therefore, the former refugees have been considered as outsiders or land users by the lembaga adat. The local institution has legitimating to claim the land. In fact that most of the government resettlement program has had to have land and house as a package for the participants, but it hasn't always occurred in Belu Regency. Consequently, the former refugees feel that their movements and activities as peasant have been limited, or even excluded and expelled as has happened in the resettlement of Taeksoruk, resettlement of Sirani, and resettlement of Aitaman. Nevertheless, the central and local government put still efforts into handling the issue.

The prominent finding in this research is family ties and other associated problems, including the internal dynamics within the community of the former refugees. It is well-known that family and ethnic ties are strong in their lives, connecting and tightening them in such a manner through social solidarity and cultural values. However, the connection is used as social networks and political sources by particular figures, such as coordinators of the former refugees and the local politicians, in order to achieve certain interests. This condition leads coordinators and prominent figures within the community into competitions, excluding each other through the local political contestations, creating distrust among the former refugees as seen in the camp of refugees of Haliwen.

Moreover, the cultural obligations also contribute to the decrease of purchasing power, having fewer opportunities to purchase land and other necessities. Furthermore, personal perceptions as being refugees or heros push them into becoming passive refugees. They believe that the government should prepare and provide them with land and a house as their necessities as a form of compensation for their properties left in East Timor and the commitment of fighters on behalf of Indonesian interests.

However, there are few successful cases showing that they have overcome land exclusion problems through several mechanisms, such as self or group supporting resettlement. Besides that, living outside the city has become a preference for a certain group of the former refugees. It is an opportunity to purchase cheap land, begin new life as peasants, and having a trading network on the border of Indonesia and East Timor as happens in the resettlement of Tohe. Meanwhile, the former refugees in the resettlement of Taeksoruk have tried to use social and cultural approaches as mechanisms to obtain a permanent land titling. They use the social relations and solidarity that have been built over the years as the basis of cooperation in order to be accepted as the new member of Liudasik tribe. However, the lembaga adat of Liudasik tribe has not yet responded to the demands made on them until the present day.

\section{References}

Achmad, J. (2000). East Timorese Refugees in West Timor. In J. J. Fox dan D. Babo-Soares (Ed.) Destruction and Reconstruction of East Timor. Canberra, ANU Press.

Agblorti, S.K.M. (2011). Refugee integration in Ghana: the host community's perspective, Research Paper No. 203, New issues in refugee research, University of Cape Coast.

Asia Foundation. (2016). Understanding Social Exclusion in Indonesia: a meta-analysis of program peduli's theory of change documents, Program Peduli.

Beall, J., \& Piron, L.H. (2005). DFID Social Exclusion Review, London School of Economics and Political Science. Bijukumar, V. (2013). Social Exclusion and Ethnicity in Northeast India, The NEHU Journal, Vol XI, No. 2, pp. 19-35. 
Bohnet, H. (2012). Large refugee populations, resource scarcity and conflict, Department of Political Science and International Relations, University of Geneva.

Borras, S.M.J.R., \& Franco, J.C. (2010). Contemporary Discourses and Contestations Around Pro-Poor Land Policies and Land Governance, Journal of Agrarian Change, Vol. 10, No. 1, pp. 1-32.

Celik, E. (2012). Bosnian Refugees in Bowling Green, Kentucky: Refugee Resettlement and Community Based Research, Master of Arts' Thesis, Department of Sociology, Western Kentucky University.

Chau, R.C.H., \& Yu, S.W.K. (2001). Social Exclusion of Chinese People in Britain, Critical Social Policy, Vol.21 (1),pp.103-125.

Duncan, C.R. (2000). the Politics Of going home: the future of North Moluccan Internally Displaced Persons, Cakalele, Vol. 11, pp. 83-111.

Hall, D., Hirsch, P., \& Li, T.M. (2013). Powers of Exclusion: Land Dilemmas in Southeast Asia, Honolulu, University of Hawai'i Press.

Harmsn, E. (2012). Review: powers of exclusion: land dilemma in Southeast Asia, the Journal of Lao Studies, Vol. 3, Issue.1,pp.132-134, ISSN: 2159-2152.

Hayes, A., Gray, M., \& Edwards. (2008). Social Inclusion: origins, concepts, and key themes, Australian Social Inclusion Unit of the Prime Minister and Cabinet Paper.

Hirsch, P. 2016). Afterword: land transformations and exclusion across regions, in "Kastom, Property and Ideology: land transformations in Melanesia", S. Mcdonnel., Allen, M., \& Filer, C., (Ed), ANU Press, Canberra

Kadun, PB., \& Gadkar, RD. (2014). Social Exclusion: its types and impact on Dalits in India, IOSR Journal of Humanities and Social Science, vol.19, issue 4, pp.81-85.

Knezevic, N. (2005). Timor-Leste: background paper on human rights, refugees, and asylum seekers, WRITENETIndependent Analysis.

Martin, A. (2005). Environmental Conflict between Refugee and Host Communities, Journal of Peace Research, vol. 42, no. 3, pp. 329-346.

Messakh, T.A. (2003). Kebijakan Pemukiman Kembali Pengungsi di Perbatasan Indonesia-Timor Leste: studi kasus Kecamatan Tasifeto Timur, Kabupaten Belu, Provinsi Nusa Tenggara Timur, Tesis Program Pascasarjana, Studi Magister Perencanaan Pembangunan Wilayah dan Kota, Universitas Diponegoro.

Pierson, J.H. (2002). Tackling Social Exclusion, London, Routledge.

Pirade, H. (2003). Dinamika Konflik Antara Komunitas Lokal Dengan komunitas Pengungsi: studi kasus pada pengungsi Timor-Timur di Kabupaten Kupang, Nusa Tenggara Timur, Master Tesis, Program Studi Sosiologi, Kekhususan Manajemen Pembangunan Sosial, Fakultas Ilmu Sosial dan Politik, Universitas Indonesia.

Okumu, J., \& Bonome, K.B. (2010). Who Belongs Where? Conflict, Displacement, Land and Identity in North Kivu, Democratic Republic of Congo.

Rame, F. (2004). Implementasi Kebijakan Resettelement Terhadap Warga Masyarakat Pengungsi Timor-Timur di Kabupaten Belu Provinsi Nusa Tenggara Timur, Master Tesis Ilmu Politik, Universitas Gadjah Mada.

Ribot, J.C., \& Peluso, N.L. (2003). A Theory of Access, Rural Sociology, Vol. 68, issue 2, pp. 153-181.

Rodgers, G. What Is Special About a Social Exclusion Approach?. In Gerry Rodgers, Charles Gore, dan Jose B. Figueiredo (Ed), 1995, Social Exclusion: rhetoric, reality, and responses, International Institute for Labour Studies, Geneva, pp. 43-56.

Sayogyo. (2009). "Reforma Agraria: perjalanan yang belum berakhir", Sayogyo Bogor Institute,

Seda, F.S.S.E., Setyawati, L., Pera, Y.H.T., Tirta, T., \& Pebriansyah. (2017). Policies, Social Exclusion, and Social Wellbeing in Indonesia and Malaysia, Senshu Social Well-Being Review, No.4, 21-35.

Sen, A. (2000). Social Exclusion: concept, application, and scrutiny, Social Development Papers, No. 1, Asian Development Bank.

Sianipar, K.D. (2016). "Resettlement of Former East Timorese Refugees in East Nusa Tenggara”. In "Observing Policy Making in Indonesia", E. Friedberg and M.E. Hilderbrand. (Ed), Springer, Singapore, pp.79-118.

Silver, H. (1995). Social Exclusion and Social Solidarity: three Paradigms, International Labour Review, Vol. 133, Discussion Papers.

Silver, H. (2005). the Process of Social Exclusion: the dynamic of an evolving concept, Chronic Poverty Research Centre, Department of Sociology, Brown University.

Unruh, J., \& Williams, R.C. (2013). Land and Post-Conflict Peacebuilding, Policy Brief, No. 3, the Environmental Law Institute.

Veneklasen, L., \& Miller, V. (2006). Dynamic or Power, Inclusion, and Exclusion, Nonprofit Online News

Vidojevic, J. (2017). Conceptualization of Social Exclusion in Africa: in search of inclusive development, 2017, Law and Development Conference, South Africa.

Zid, M., \& Alkhudri, A.T. (2016). "Sosiologi Pedesaan: teoritisasi dan perkembangan pedesaan di Indonesia", Jakarta, Raja Grafindo Persada. 